\title{
Growth Performance, Carcass Quality, Organ Weights and Haematology of Broilers Fed Graded Dietary Levels of Turmeric (Curcuma longa L.) Powder as Feed Additive
}

\author{
Paul Milverton Eko, Kolawole Daniel Afolabi*, Glory Eddy Enyenihi \\ Department of Animal Science, University of Uyo, Uyo, Akwa Ibom State, Nigeria \\ Email address: \\ pamvotek@gmail.com (P. M. Eko),kaydafl@yahoo.com (K. D. Afolabi),gloryenyenihi@yahoo.com (G. E. Enyenihi) \\ ${ }^{*}$ Corresponding author
}

To cite this article:

Paul Milverton Eko, Kolawole Daniel Afolabi, Glory Eddy Enyenihi. Growth Performance, Carcass Quality, Organ Weights and Haematology of Broilers Fed Graded Dietary Levels of Turmeric (Curcuma longa L.) Powder as Feed Additive. Animal and Veterinary Sciences. Special Issue: Promoting Animal and Veterinary Science Research. Vol. 8, No. 3, 2020, pp. 65-70. doi: 10.11648/j.avs.20200803.14

Received: April 20, 2020; Accepted: May 22, 2020; Published: June 28, 2020

\begin{abstract}
The growth performance, carcass qualities, organs weight and haematology of ninety-six (96) day-old Agritech broiler birds fed Turmeric powder additive were evaluated. The birds were reared on deep litter system and were randomly allotted to four (4) treatments of graded dietary levels $\left(0,1.5,3.0\right.$ and 4.5\%) of Turmeric powder denoted as; $\mathrm{T}_{1}, \mathrm{~T}_{2}, \mathrm{~T}_{3}$ and $\mathrm{T}_{4}$ respectively. Each treatment with 24 birds was also replicated thrice with 8 birds per replicate in a Completely randomized design for 56 days. Performance indicators measured included feed intake, body weight gain, feed conversion ratio, carcass and organ weights and haematological parameters. Results showed that turmeric additive elicited significant differences $(\mathrm{P} \leq$ $0.05)$ across treatments. Bodyweight gain $(2113.00 \mathrm{~g})$ and feed conversion ratio (2.02) were significantly higher in broilers fed diets with $1.5 \%$ turmeric powder $\left(\mathrm{T}_{2)}\right.$ than those on other treatments. Turmeric additive also improved the carcass and organ weights as well as the haematological parameters in which the erythrocytic and leukocytic counts were not significantly different $(P \geq 0.05)$ in $T_{2}, T_{3}$ and $T_{4}$ except for the control. However, the overall positive effect of turmeric powder in broiler diet was observed in $\mathrm{T}_{2}(1.5 \%)$ following improved feed intake, body weight gain and feed conversion ratio and this inclusion level is advocated while further research in other avian species available in warm wet regions of Nigeria is suggested.
\end{abstract}

Keywords: Performance, Haematology, Broiler, Turmeric, Feed Additive

\section{Introduction}

Broiler production has turned into a dynamic industry with potentials to solve malnutrition and unemployment, poverty reduction as well as encouraging income generation $[1,2]$. Broilers have fast growth rate, high carcass yield, efficiency of feed utilization, short generation period, ease of management and small space requirement [3, 4]. However, broiler industry has several challenges amongst the high cost of feed ingredients. Feeds account for about $65-75 \%$ of the total cost of production [5] and in bracing up the challenge of high cost of feeds, broiler operators are unrelently making efforts to explore alternative feed ingredients including feed additives which are used as antibiotics, anti-oxidants, binders, colourants and lubricants [6].

The plethora of criticisms on adverse effects of using synthetic antibiotics and their complete ban by the European Union and United State Departments of Agriculture in 2006 have given rise to search for natural, plant-based feed additives known as phytobiotics [7, 8]. Phytobiotics are believed to prevent diseases, improve flavour and palatability of feeds [9]. Phytobiotics Feed Additives (PFAs) have also been regarded as safe to the birds, operators, consumers and the environment $[8,10]$.

Given the interest and benefits from using phytobiotics, extensive research works have been conducted and reported on the wide use of several plants as phytobiotic feed additives in broiler diets. One of such plants is Tumeric (Curcuma long $L$.), a perennial herb belonging to Zingiberaceae family. The rhizome is the part used both as spice and feed additive after it is cleaned, boiled and dried to yield yellow powder [11, 12]. Phytochemical analysis of Turmeric rhizome had been reported $[13,14]$ to 
contain Curcuminoids which is made up of Curcumin I (94\%) and Curcumin II (6\%), protein $(6.3 \%)$, fat (5.1\%), carbohydrates $(69.4 \%)$, minerals $(3.5 \%)$, essential oils $(5.8 \%)$ and moisture $(13.1 \%)$. Curcumin has been described $[8,15,16]$ as the main yellow bioactive component that has a wide spectrum of biological, medical and pharmacological actions as anti-oxidant, antibacterial, antiviral, antifungal, antiprotozoal, anticarcinogenic, anti-inflammatory, immunomodulatory, heptoprotective and hypocholesteremic activities. Curcumin is estimated to be $2-5 \%$ of Turmeric and its content in Turmeric can be influenced by species diversity, different stages of growth at which the plant is harvested, difference in regions, soil nutrients and acidity [17]. Curcumin is non-toxic residue free and well tolerated at very high doses in broilers.

Despite numerous experiments conducted on Turmeric as phytobiotic feed additives in broiler diets, there is still paucity of reliable or consistent reports regarding the herb efficacy on performance parameters. Therefore, this current study was initiated to investigate the effect of turmeric additive on growth performance, carcass qualities, organ weights and haematology of broilers reared in warm wet climate.

\section{Materials and Method}

\subsection{Study Site}

The study was conducted at the Poultry Unit, Teaching and Research Farm of the Department of Animal Science, University of Uyo Akwa Ibom State, Nigeria located on Latitude $5^{\circ} 17^{`}$ and $5^{\circ} 27^{\prime}$ North of the Equator and Longitude $7^{\circ} 27^{\prime}$ and $7^{\circ} 58^{\prime}$ East of the Greenwich with temperature ranges between $26^{\circ} \mathrm{C}-28^{\circ} \mathrm{C}$ and average annual rainfall range of $2000 \mathrm{~mm}-3000 \mathrm{~mm}$. Relative humidity ranges between $78 \%-93 \%([18]$.

\subsection{Experimental Birds and Management}

Ninety-six day old broiler chicks of Agrictech strain were purchased in Uyo, Akwa Ibom State, Nigeria. The birds were reared on deep litter system. All vaccines and drugs were administered. Sufficient warmth and light were also supplied as recommended [19].

The experiment lasted for 8 weeks. The formulated starter mash and water were provided ad libitum at 0-4 weeks. At the end of the 4th week, the birds were weighed and fed on the formulated finisher mash from 5 - 8 weeks. Daily feed intake was recorded as difference of feed offered and left over.

\subsection{Experimental Design}

Upon arrival, the day-old chicks were weighed and randomly allotted to 4 dietary treatments of 24 birds. Each treatment was replicated 3 times with 8 birds per replicate in a Completely Randomized Design (CRD)

Birds in $\mathrm{T}_{1}$ were fed basal diet, while $\mathrm{T}_{2}, \mathrm{~T}_{3}$ and $\mathrm{T}_{4}$ were fed basal diets containing $1.5 \%, 3.0 \%$ and $4.5 \%$ Turmeric powder as additive respectively during the 8 weeks of experimental period.

\subsection{Processing of Turmeric}

Fresh Turmeric rhizomes (Curcuma longa L.) used for this experiment were purchased from a local market in Uyo, Akwa Ibom State. These rhizomes were washed, sliced, boiled for 45 minutes and oven -dried at $50^{\circ} \mathrm{C}$ for 24 hours and then ground into powder [17]. The turmeric powder so obtained was incorporated into the experimental diets which were analyzed for proximate composition using the official methods [20].

\subsection{Blood Collection and Carcass Analysis}

The blood samples were collected from each of the 24 birds. $2.5 \mathrm{ml} \%$ blood samples taken from the wing veins of the selected birds were put in labeled sterile bottles containing EDTA to determine haematological indices [21].

At the end of the experimental period, 2 birds per replicate were randomly selected and fasted for 18 hours to 24 hours to empty their GIT after which they were weighed alive and slaughtered by cervical dislocation [22].

The carcasses were weighed again before evisceration to extract liver, heart, spleen, pancreas and intestines, while the wing, drumstick, thigh, breast cut and back cut were also obtained from the carcasses.

These organs were weighed with Sensitive Scale (A \& Gulf, JS $600 \mathrm{H}$ ) and were also examined to detect any lesion or damage.

\subsection{Data Collection}

Data considered and collected were performance indices involving feed intake body weight gain, feed conversion ratio, carcass/organ weights and haematological parameters. The mean weekly feed intake and body weight gain for each treatment group were recorded throughout the experimental period and used to determine FCR.

\subsection{Statistical Analysis}

Data obtained were subjected to Analysis of Variance [23] and the means were separated using Duncan Multiple Range Test [24] at 5\% level.

Table 1. Ingredient composition (\%) of experimental diets with graded dietary levels of Turmeric powder.

\begin{tabular}{|c|c|c|c|c|c|c|c|c|}
\hline \multirow{2}{*}{ Treatments } & \multicolumn{4}{|c|}{ Starter Phase } & \multicolumn{4}{|c|}{ Finisher Phase } \\
\hline & T1 & T2 & T3 & T4 & T1 & T2 & T3 & T4 \\
\hline Turmeric powder $(\%)$ & 0 & 1.5 & 3.0 & 4.5 & 0 & 1.5 & 3.0 & 4.5 \\
\hline \multicolumn{9}{|l|}{ Ingredients: } \\
\hline Maize & 49.0 & 49.0 & 49.0 & 49.0 & 62.0 & 62.0 & 62.0 & 62.0 \\
\hline Soybean meal & 34.0 & 34.0 & 34.0 & 34.0 & 25.0 & 25.0 & 25.0 & 25.0 \\
\hline
\end{tabular}




\begin{tabular}{lllllllll}
\hline \multirow{2}{*}{ Treatments } & \multicolumn{2}{l}{ Starter Phase } & \multicolumn{5}{c}{ Finisher Phase } \\
\cline { 2 - 8 } & T1 & T2 & T3 & T4 & T1 & T2 & T3 & T4 \\
\hline Palm kernel cake & 5.20 & 3.70 & 2.20 & 0.70 & 4.20 & 2.70 & 1.20 & 0.00 \\
Wheat offal & 5.00 & 5.00 & 5.00 & 5.00 & 5.00 & 5.00 & 5.00 & 5.00 \\
Fish meal & 3.00 & 3.00 & 3.00 & 3.00 & 3.00 & 3.00 & 3.00 & 3.00 \\
Turmeric & 0.00 & 1.50 & 3.00 & 4.50 & 0.00 & 1.50 & 3.00 & 4.50 \\
Bone meal & 3.00 & 3.00 & 3.00 & 3.00 & 3.00 & 3.00 & 3.00 & 3.00 \\
Salt & 0.25 & 0.25 & 0.25 & 0.25 & 0.25 & 0.25 & 0.25 & 0.25 \\
Lysine & 0.20 & 0.20 & 0.20 & 0.20 & 0.20 & 0.20 & 0.20 & 0.20 \\
Methionine & 0.10 & 0.10 & 0.10 & 0.10 & 0.10 & 0.10 & 0.10 & 0.10 \\
*Vitamin Premix & 0.25 & 0.25 & 0.25 & 0.25 & 0.25 & 0.25 & 0.25 & 0.25 \\
Total & 100 & 100 & 100 & 100 & 100 & 100 & 100 & 100 \\
Crude Protein (\%) & 22.86 & 22.73 & 22.59 & 22.46 & 20.21 & 20.05 & 19.89 & 19.78 \\
ME (kcal/kg) & 2843.2 & 2826.8 & 2803.6 & 2783.5 & 2951.0 & 2931.2 & 2911.4 & 2896.6 \\
Calcium (\%) & 1.20 & 1.46 & 1.70 & 1.96 & 1.18 & 1.44 & 1.68 & 1.94 \\
Phosphorous & 0.81 & 1.26 & 1.71 & 2.15 & 0.71 & 1.15 & 1.61 \\
\hline
\end{tabular}

*Vitamin premix per kg of diet: Mg, Vit. A, 2.7 (iu/kg); Vit D3, 0.005 (iu/kg); Vit. E, 18 (ppm); Vit. K3, 2 (iu/kg); Thiamin, 1.8 (ppm); riboflavin, 6.6 (ppm); pantothenic acid, 10 (ppm); pyridoxin, 3 (ppm); cyanocobalamin, 0.015 (ppm); niacin, 30 (ppm); biotin, 0.1 (ppm); folic acid, 1 (ppm); choline chloride, 250 (ppm); antioxidant, 100 (ppm). ME = Metabolizable energy.

\section{Results and Discussion}

The growth performance of broiler chicken fed graded dietary levels of Turmeric powder for 56 days on deep litter house is as shown in Table 2 below. There were significant differences $(\mathrm{P}<0.05)$ observed for all the parameters measured. Feed intake showed a higher increase in $\mathrm{T}_{2}$ (4261g) as compared with other treatments except the control. The body weight for birds fed diets with $1.5 \%$ turmeric powder $(2193 \mathrm{~g})$ and those on control diet $(2137 \mathrm{~g})$ significantly decreased with increasing levels of dietary Turmeric powder to $1833 \mathrm{~g}$ and $1551 \mathrm{~g}$ for those fed diets with 3.0 and $4.5 \%$ respectively. Regarding the feed conversion ratio, birds fed $1.5 \%$ dietary Turmeric powder were adjudged the best followed by the control diet.

Table 2. Growth Performance of broiler chicken fed graded dietary levels of Turmeric Powder.

\begin{tabular}{|c|c|c|c|c|c|}
\hline Treatments & $\mathbf{T}_{1}$ & $\mathbf{T}_{2}$ & $\mathbf{T}_{3}$ & $\mathbf{T}_{4}$ & SEM \\
\hline Turmeric powder (\%) & 0 & 1.5 & 3.0 & 4.5 & \\
\hline \multicolumn{6}{|l|}{ Parameters: } \\
\hline Initial body weight (g/bird) & 80.00 & 80.00 & 80.00 & 80.00 & 0.00 \\
\hline Final body weight (g/bird) & $2137^{\mathrm{a}}$ & $2193^{a}$ & $1833^{\mathrm{b}}$ & $1551^{\mathrm{c}}$ & 18.26 \\
\hline Body Weight gain (g/bird) & $2057^{\mathrm{a}}$ & $2113^{\mathrm{a}}$ & $1753^{\mathrm{b}}$ & $1471^{\mathrm{c}}$ & 18.26 \\
\hline Feed intake $(\mathrm{g} / \mathrm{bird}\}$ & $4197^{\mathrm{a}}$ & $4261^{\mathrm{a}}$ & $3868^{\mathrm{b}}$ & $3771^{\mathrm{b}}$ & 31.06 \\
\hline Daily Weight gain (g/bird/day) & $41.99^{\mathrm{a}}$ & $43.12^{\mathrm{a}}$ & $35.77^{\mathrm{b}}$ & $30.02^{\mathrm{b}}$ & 0.37 \\
\hline Daily Feed intake (g/bird/day) & $85.66^{\mathrm{a}}$ & $86.96^{\mathrm{a}}$ & $78.92^{\mathrm{b}}$ & $76.95^{\mathrm{b}}$ & 0.63 \\
\hline Feed Conversion Ratio (FCR) & $2.04^{\mathrm{c}}$ & $2.02^{\mathrm{c}}$ & $2.21^{\mathrm{b}}$ & $2.56^{\mathrm{a}}$ & 0.02 \\
\hline
\end{tabular}

${ }^{\text {a-c }}$ Means along the same row with different superscripts are significantly different $(\mathrm{P}<0.05)$

$\mathrm{SEM}=$ Standard Error of means.

Improvement in feed intake, body weight gain and feed conversion ratio obtained for birds fed $1.5 \%\left(\mathrm{~T}_{2}\right)$ over other treatments might be attributed to the presence of bioactive compound called Curcumin in turmeric powder. Curcumin is a natural antioxidant that stimulates protein synthesis in birds' enzymatic system [19]. As an antioxidant, Curcumin can destroy free radical, increase antioxidant enzymes and inhibit lipid peroxidation [26]. The findings also agreed with $[17,25$,] who reported positive effects of turmeric on bodyweight gain (2277g and $1287.4 \mathrm{~g})$ and feed conversion ratio (1.87 and 2.27) of finisher broilers. It has also been observed [12] that broilers fed with diets supplemented with $5 \mathrm{~g} / \mathrm{kg}$ turmeric powder had better feed conversion ratio than that of $2.5 \mathrm{~g}$ and $10 \mathrm{~g} / \mathrm{kg}$ supplementation levels. This beneficial effect as observed by [17] was attributed the beneficial effect of turmeric to its antimicrobial properties as it limits the growth and colonization of numerous pathogenic and non-pathogenic species of bacteria in chickens' gut, thus resulting in balanced gut microbial ecosystems which enhanced better feed utilization as reflected by improved FCR. It was also reported [27] that inclusion of $3 \mathrm{~g}$ and $6 \mathrm{~g} / \mathrm{kg}$ of turmeric to the aflatoxin contaminated diet indicated improved feed conversion ratio when compared with birds fed contaminated diets alone.

The decrease in feed intake and body weight gain in $T_{3}$ and $\mathrm{T}_{4}$ might also be attributed to higher percentage of turmeric powder causing excessive bitter taste that prevent birds from taking more of the diet. A reduced feed intake had been reported $[12,28]$ when turmeric additive (even at $2 \mathrm{~g} / \mathrm{kg}$ ) was fed to chicken. 
The haematological parameters of broilers fed diets with different levels of Turmeric powder is as shown in Table 3 below. Broilers fed diets with Tumeric powder $\left(\mathrm{T}_{2}, \mathrm{~T}_{3}\right.$ and $\mathrm{T}_{4}$ ) were similar $(\mathrm{P}>0.05)$ in values for $\mathrm{RBC}$ and $\mathrm{WBC}$, but significantly higher than what obtained for those on control treatment (RBC, $1.82 \times 10^{3} / \mu \mathrm{l}$; WBC, $191.03 \times 10^{6} / \mu \mathrm{l}$ ).
Studies by [25] demonstrated a significant increase in values of erythrocytes at 268,000 and leukocytes at 3,000,200 when the diet of broiler chicken was supplemented with $10 \mathrm{~g} / \mathrm{kg}$ turmeric meal. A significant increase in erythrocytic count had been reported [8, 18, 29], following the inclusion of $600 \mathrm{mg} / \mathrm{kg}$ of Tumeric in broiler diet.

Table 3. Haematological parameters of broilers fed diets with different levels of Turmeric powder.

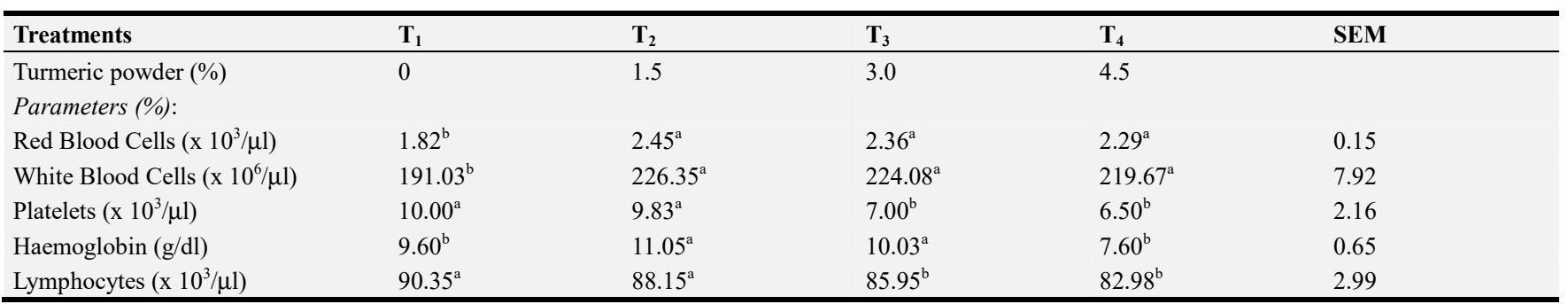

${ }^{\mathrm{a}-\mathrm{c}}$ Means along the same row with different superscripts are significantly different $(\mathrm{P}<0.05)$

The platelet and lymphocytes values obtained for broiler fed diets with $3.0 \%$ curcumin $\left(7.0\right.$ and $85.95 \times 10^{3} / \mu 1$ respectively) and $4.5 \%$ curcumin powder (6.50 and $82.98 \mathrm{x}$ $\left.10^{3} / \mu 1\right)$ were similar and significantly lower than the values obtained for those on control treatment (10.0 and $9.83 \mathrm{x}$ $10^{3} / \mu 1$ respectively) and $1.5 \%$ curcumin powder. Turmeric powder had been reported [17] to promote the activation of T-lymphocytes, B-lymphocytes, macrophages, neutrophils and natural killer cells in chickens. These improvements in many haematogical parameters might be attributed to the immunomodulatory activity of Curcumin $[8,17]$.

As the level of curcumin powder increased in the diet to $3.0 \%$ the haemoglobin significantly increased to $10.03 \mathrm{~g} / \mathrm{dl}$ after which it dropped significantly to $7.60 \mathrm{~g} / \mathrm{dl}$ at $4.5 \%$ inclusion level of curcumin powder which is similar to what obtained for birds on control treatment without curcumin powder. Higher levels of curcumin as a result of increasing levels of turmeric powder in broiler chicken's diet up to $4.5 \%$ might have negative effects on haemoglobin, platelets and lymphocytes as observed in this study.

Haematological parameters obtained from the current study had values within the limits reported in the literature [21] and their increased rates might be due to the positive effects of Curcumin, the bioactive substance in turmeric, on blood parameters as reported by some researchers earlier [8, 29]. Both leukoytic and erythrocytic values in this study are also in line with what had been reported [25] that increase in $\mathrm{WBC}$ and $\mathrm{RBC}$ can be attributed to the immune stimulatory activity of Curcumin. The normal ranges for $\mathrm{RBC}, \mathrm{WBC}$, Haemoglobin, PCV and Lymphocytes in broiler chickens had been put at $2.0-4.0 \times 10^{3} \mathrm{~mm}, 3.0-6.0 \times 10^{3} \mathrm{~mm}, 7.0-$ $13.0 \mathrm{~g} / \mathrm{dl}, 25-45 \%$ and $50 \%$ respectively [30].

The carcass and organ weights (expressed as\% body live weight) of broiler chicken fed diets with different levels of Turmeric powder is as shown in Table 4 below. Broilers fed diets with up to $1.5 \%$ turmeric powder had significantly higher body weights and dressed weights than those on $3 \%$ turmeric powder which in turn was significantly higher than those on diet with $4.5 \%$ turmeric powder. Increase in the inclusion level of turmeric powder beyond 1.55 elicited a significant decrease in body live weights and dressed weights, though the dressing percentage were similar across treatments. The carcass and organ weights showed that birds fed with diet containing $1.5 \%$ of Turmeric powder had significantly $(\mathrm{p}<0.05)$ higher values than those fed diets with 3.0 (T3) and 4.5\% (T4) turmeric powder.

Significantly $(\mathrm{p}<0.05)$ higher weights for cut parts such as wing $(13.08 \%)$, drumstick $(14.86 \%)$, thigh $(15.96 \%)$, breast cut $(30 \%)$, back cut $(25.09 \%)$, and neck $(6.22 \%)$ and selected organs like the heart $(0.92 \%)$, lungs $(0.86 \%)$, liver $(3.36 \%)$, spleen $(0.24 \%)$, pancreas $(0.41 \%)$, small intestine $(7.20 \%)$ and large intestine $(0.33 \%)$ were obtained for broilers fed diet with $1.5 \%$ turmeric powder. These weights decreased across other dietary treatments with increasing levels of turmeric powder.

The results from the data also revealed that carcass and organ parameters were significantly affected $(\mathrm{p}<0.05)$ by dietary inclusion levels of turmeric powder. This observation might be due to the effect on growth performance such as body weight gain obtained during the rearing period. Improved carcass quality, dressing percentage as well as increase in breast cut, thigh and giblet weight had been reported [12] in broilers fed diet with $5 \mathrm{~g} / \mathrm{kg}$ turmeric powder supplementation, while $3 \mathrm{~g} / \mathrm{kg}$ Turmeric diet supplementation reduced carcass fat content and improved carcass quality in broilers [8]. The body weight of birds fed turmeric powder at $5 \mathrm{~g} / \mathrm{kg}$ was attributed $[8,12]$ to the stimulation of protein synthesis in birds' enzymatic system and the weight increase could be attributed to the control of growth of pathogenic bacteria in the chickens' gut by the antimicrobial properties of curcumin in turmeric, thus ensuring a balanced microbial ecosystem that enhance better feed utilization. These beneficial effects may, in turn, be responsible for tissue, bone and organ development, hence reasonable appreciation or increase in weight. Similar positive effects from reduced fat content on carcass, thigh, pancreas and intestines had also been reported [26, 28]. Some researchers [31] also reported a better dressing percentage $(78.06 \%)$ and carcass yield [32] 
when broilers were fed diets with up to $7.5 \mathrm{~g} / \mathrm{kg}$ and $1.0 \%$ turmeric powder respectively which was attributed to the positive influence of turmeric powder as growth promoter that led to more gain in body weight of the broilers.

Table 4. Carcass and Organ weights (expressed as\% body live weight) of broiler chicken fed diets with different levels of Turmeric powder.

\begin{tabular}{|c|c|c|c|c|c|}
\hline Treatments & $\mathbf{T}_{1}$ & $\mathbf{T}_{2}$ & $\mathbf{T}_{3}$ & $\mathbf{T}_{4}$ & SEM \\
\hline Turmeric powder $(\%)$ & 0 & 1.5 & 3.0 & 4.5 & \\
\hline \multicolumn{6}{|l|}{ Parameters: } \\
\hline Live weight /bird (g) & $1917^{\mathrm{a}}$ & $1983^{\mathrm{a}}$ & $1717^{\mathrm{b}}$ & $1417^{\mathrm{c}}$ & 47.10 \\
\hline Dressing percentage & 80.00 & 80.00 & 80.00 & 80.00 & 0.82 \\
\hline \multicolumn{6}{|l|}{ Cut Parts (\%): } \\
\hline Wing & $10.26^{\mathrm{b}}$ & $13.08^{\mathrm{a}}$ & $10.40^{\mathrm{b}}$ & $10.33^{\mathrm{b}}$ & 0.27 \\
\hline Thigh & $13.55^{\mathrm{b}}$ & $15.96^{\mathrm{a}}$ & $13.09^{\mathrm{b}}$ & $12.24^{\mathrm{c}}$ & 0.33 \\
\hline Breast cut & $29.08^{\mathrm{ab}}$ & $30.00^{\mathrm{a}}$ & $27.88^{\mathrm{b}}$ & $25.97^{\mathrm{c}}$ & 0.71 \\
\hline Back cut & $21.97^{\mathrm{b}}$ & $25.09^{\mathrm{a}}$ & $20.85^{\mathrm{b}}$ & $18.18^{\mathrm{c}}$ & 0.55 \\
\hline Neck & $5.77^{\mathrm{b}}$ & $6.22^{\mathrm{a}}$ & $5.57^{\mathrm{b}}$ & $4.83 \mathrm{c}$ & 0.14 \\
\hline \multicolumn{6}{|l|}{ Organ weights (\%): } \\
\hline Caecum & $0.89^{\mathrm{b}}$ & $1.12^{\mathrm{a}}$ & $0.76^{\mathrm{c}}$ & $0.84^{\mathrm{b}}$ & 0.02 \\
\hline Heart & $1.04^{\mathrm{a}}$ & $0.92^{\mathrm{b}}$ & $0.67^{\mathrm{c}}$ & $1.02^{\mathrm{a}}$ & 0.02 \\
\hline Proventriculus, Crop \& Gizzard & $4.02^{\mathrm{ab}}$ & $5.04^{\mathrm{a}}$ & $4.01^{\mathrm{ab}}$ & $2.62^{b}$ & 0.66 \\
\hline Spleen & $0.25^{\mathrm{a}}$ & $0.24^{\mathrm{a}}$ & $0.19^{\mathrm{b}}$ & $0.14^{\mathrm{c}}$ & 0.01 \\
\hline Gall bladder & $0.18^{\mathrm{a}}$ & $0.19^{\mathrm{a}}$ & $0.16^{\mathrm{b}}$ & $0.11^{\mathrm{c}}$ & 0.01 \\
\hline Pancreas & $0.39^{\mathrm{b}}$ & $0.41^{\mathrm{c}}$ & $0.45^{\mathrm{b}}$ & $0.48^{\mathrm{c}}$ & 0.01 \\
\hline Small intestine & $6.27^{\mathrm{b}}$ & $7.20^{\mathrm{a}}$ & $5.70^{\mathrm{c}}$ & $5.43^{\mathrm{c}}$ & 0.15 \\
\hline Large intestine & $0.23^{\mathrm{b}}$ & $0.33^{\mathrm{a}}$ & $0.21^{\mathrm{c}}$ & $0.14^{\mathrm{d}}$ & 0.01 \\
\hline Lungs. & $0.77^{\mathrm{b}}$ & $0.86^{\mathrm{a}}$ & $0.86^{\mathrm{a}}$ & $0.76^{\mathrm{b}}$ & 0.02 \\
\hline
\end{tabular}

${ }^{\mathrm{a}-\mathrm{d}}$ Means along the same row with different superscripts are significantly different $(\mathrm{p}<0.05)$. SEM $=$ Standard error of means.

\section{Conclusion}

Feeding broiler chicken with diet that contain up to $1.5 \%$ turmeric powder induced better growth, carcass, and organic weight as well as haematological performances which has promoted the positive effects of Curcumin in poultry nutrition.

Besides, given the promising status of Turmeric as a nontoxic and natural phytobiotic feed additive, it is suggested that further research be undertaken on other avian species available in the warm wet regions as well as devising efficient storage methods and conditions for making Turmeric powder available all year round since its present scanty cultivation remains a major challenge to its use in research.

\section{Acknowledgements}

The authors are grateful to the Management of the University of Uyo for the use of its facilities at the Teaching and Research Farm and the Laboratory during the research.

\section{References}

[1] Eko, P. M., Udoh, U. H. and Edem, I. D. (2014). Contributions of different litter levels on birds' performance, quality of poultry droppings on soil nutrients and percent seed emergence of Cowpea (Vigna unguiculata) in acid sand. International Journal of Agriculture and Forestry 4 (2): 73-74.

[2] Nworgu, F. C., Oduola, O. A., Falola, D. O., Adebose, T. K.,
Olajide, M. O., Akingbogun, S. A. and Oguntayo, C. T. (2012). Effects of wilted waterleaf (Talinuin triangulare) leaves on the performance of growing pullets. Proceeding of the 37th Annual Conference of the Nigerian Society for Animal Production, 315p

[3] Odukoya, S. O. Adedeji, A. Y. and Temola, A. A. (2014). Effect of feeding frequency on the performance characteristics of broiler chickens. In: Abdullahi, A. R. (eds). Proceedings of the $39^{\text {th }}$ Annual Conference, Nigerian Society for Animals Production. Pp. 561.

[4] Owen, O. J., Amakiri, A. O. and Faaka, K. G. (2013). Performance indices of broiler chickens administered Garlic (Allium sativum) feed additive. In: Oruwari, B. M. (eds). Proceedings of the 38 and 40 Annual Conference, Nigerian Society for animal Production, 505p.

[5] Fatokun, B. O., Idris, A. S., Ukandu, P. and Olajide, O. B. (2010). Haematological changes observed in cockerel chickens fed with graded levels of raw Gmelina arboreal seed meal. In: Ifut, O. J. (eds), Proceedings of the $15^{\text {th }}$ Annual Conference Nigerian Society for Animal Production, pp. 315.

[6] Olomu, J. M. (2011) Monogastric animal Nutrition: Principles and Practice (2nd ed.) Benin, St. Jackson Publishing, p. 278.

[7] Windisch, W., Schedle, K., Plitzner, C. and KroisMayr, A. (2008). Use of phytogenic products as feed additives for swine and poultry. Journal of Animal Science 86: 140-148.

[8] Dono, N. D. (2013). Tumeric (Curcuma longa L). Supplementation as an alternative to antibiotics in poultry diets. WARTAZOA, 23 (1): 41-46.

[9] Mohammed, A. A. and Yusuf, M. (2014). Evaluation of Ginger (Zingiberofficinale) as a feed additive in broiler diets. Livestock Research for Rural Development, 23 (9): 1-2. 
[10] EL-Husseiny, O. M., Abdallah, A. G. and Abdel-Latif, K. O. (2008). The influence of biological feed additives on broiler performance. International Journal of Poultry Science 7 (9): 862-871.

[11] Budhwaar, V. (2010). The Secret Benefits of Ginger and Tumeric. India, New Dawn Press, Pages 66-82.

[12] Durrani, F. R., Mohammed, I., Asad S., Shail, S. M., Naila, C. and Durrani, Z. (2006). Effect of different levels of feed added Tumeric (Curcuma longa) on the performance of broiler chicks. J. Agric. Biol. Sci. 1 (2): 9-10.

[13] Bagchi, A. (2012). Extraction of Curcumin. Journal of Environmental Science and Toxicology and Food Technology $1(3): 1-16$.

[14] Jurenka, J. S. (2009). Anti-inflammatory properties of Curcumin, a major constituent of Curcuma longa. A Review of Preclinical and Clinical Research. Alternative Medicine Review 14 (2): 141.

[15] Jaggi, L. (2012). Tumeric, Curcumin and Our Life: A Review Bulletin of Environment, Pharmacology and Life Sciences 7: 11-17.

[16] Chattopadhyay, I., Biswas, K., Bandyopadhyay, U. and Banerjee, R. K. (2004). Tumeric and Curcumin. Biological actions and medical applications. Current Science 87 (1): 4446.

[17] Nouzarian, R., Tabeidian, S. A., Toghyani, M., Ghelamkari, G. and Toghyani, M. (2011) Effect of Tumeric powder on performance, carcass traits, humoral immune responses and serum metabolites in broiler chickens. Journal of Animal and Feed Science, 20: 389-400.

[18] Akpabio, I. A. and Chukukere, O. C. (2004). Profitability of Poultry Egg Production in Uyo Metropolis of Akwa Ibom State, Nigeria. Discuss Paper 10, Agric. Economics and Extension Department, University of Uyo, Nigeria. Page 28.

[19] Oluyemi, J. A. and Roberts, F. A. (2000). Poultry Production in Warm Wet Climates ( $2^{\text {nd }}$ ed.), Ibadan, Spectium Books Ltd, p. 244.

[20] AOAC (2006). Official Methods of Analysis $18^{\text {th }}$ Association of Official Analytical Chemists, Arlington, V. A. USA, page 16.

[21] Mitruka, B. M. and Rawnsley, H. M. (1977). Clinical Biochemical and Haematological Reference Values in Normal Experimental Animals, Philadephia, Masson Publishing USA. Inc, N. Y. pages $86-88$.
[22] Sonaiya, E. B., Williams, A. R. and Oni, S. A. (1986). Biological economic appraisal of broiler production up to 16 weeks. Journal of Animal Sci. Res. 6 (2): 112-125.

[23] Steel, R. G. and Torrie, H. (1980). Principal and Procedure of Statistics. A Biometric Approach ( $2^{\text {nd }}$ ed), New York, McGraw Hill Book. Pages. 113-114.

[24] Duncan, B. (1955). Multiple Ranges and Multiple F-test. Biometrics 11: 1-14 Reddy,, N. R M. E Press, New York pp. 143-153.

[25] AL-Sultan, S. I. (2003). The effect of Curcuma longa, (Tumeric) on the overall performance of broiler chickens. International Journal of Poultry Science 2 (5): 351-353.

[26] Prasad, S. and Aggarwal, B. B. (2011). Tumeric, the Golden spice: From traditional medicine to modern medicine. In: Benzie and Watchtel (eds) Herbal medicine. Bimolecular and clinical aspects (2ed), Boca Raton, CRC Press, p. 14.

[27] Ahmadi, F. (2010). Effect of Tumeric (Curcuma longa L.) powder on performance oxidative stress state and some of the blood parameters in broilers fed diets containing aflatoxin $B_{1}$. Glob. Vet. 5: 312-317.

[28] Emadi, M. and Kermanshahi, H. (2006). Effect of Tumeric rhizome powder on performance and carcass characteristics of broiler chickens. International Journal of Poultry Science 5: 1069-1072.

[29] Sugiharto, I., Widiastuti, E. and Prabowo, N. S. (2011). Effect of Tumeric extract on blood parameters, feed efficiency and abdominal, fat content in broilers. Indonesian Trop. Anim. Agric. 36: 21-26.

[30] Ajuonuma, O. O. and Awodi, A. B. (2012). Effect of Molasses on Haematology of Broiler Chickens. In: Bitto, I. I. (ed). Proceedings of the $37^{\text {th }}$ Annual Conference, Nigerian Society for Animal Production. Pp. 198.

[31] Shohe, A., Vidyarthi, V. K. and Zuyie, R. (2019). Performance of Broiler Chicken on Diet Supplemented with Turmeric Powder (Curcuma longa). Livestock Research International 7 (2): 77-82. www.jakraya.com/journa/lri

[32] Mondal, M. A., Yeasmin, T., Karim, R. Siddiqui, M. N., Raihanun-Nabi, S. M., Sayed, M. A. and Siddiky, M. N. A. (2015). Effect of dietary supplementation of Turmeric (Curcuma longa) powder on the growth performance and carcass traits of broiler chicks. SAARC Journal of Agriculture, $13 \quad$ (1): 188-199. https://www.banglajol.info/index.php/SJA/article/view/24191 